\title{
GENOGRAM VISUALIZATION USING SOCIAL NETWORK APPROACH FOR MEDICAL FAMILY TREE
}

\section{SITI FATIMAH BINTI BOKHARE}




\section{GENOGRAM VISUALIZATION USING SOCIAL NETWORK APPROACH FOR MEDICAL FAMILY TREE}

by

\section{SITI FATIMAH BINTI BOKHARE}

Thesis submitted in fulfillment of the requirements

for the degree of

Master of Science

August 2018 


\section{ACKNOWLEDGEMENT}

In the name of Allah, the most gracious and the most merciful. Alhamdulillah, highest praise to Allah for his wills that gave me the strength and patience to complete this thesis and made all things possible

Foremost, I would like to express my sincere gratitude to Dr Wan Mohd Nazmee Wan Zainon as my supervisor and my co-supervisor, Prof. Dr Abdullah Zawawi Talib for their continuous support of my master study and research, for their patience, motivation, enthusiasm, and immense knowledge. Their guidance helped me in all the time of research and writing of this thesis. I could not have imagined having a better supervisor and co-supervisor for my master study.

I acknowledge, appreciate, and return the love and support of my family, without whom I would be lost, especially to my husband Fadzli and my son Muhammad who have been my emotional anchors through not only during my study years, but my entire life. Both my parents, siblings and their family have also become an important part of my world. I am forever indebted to all my family members for their affection, support, and constant encouragement.

Thanks to many current and former people and all lab members at the School of Computer Sciences USM for their help and friendship over the years. 


\section{TABLE OF CONTENTS}

Acknowledgement................................................. ii

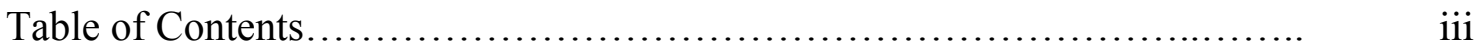

List of Tables....................................................... vii

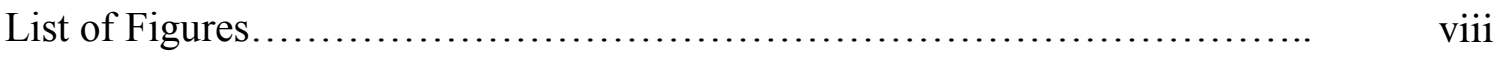

Abstrak............................................................

Abstract.......................................................... xiv

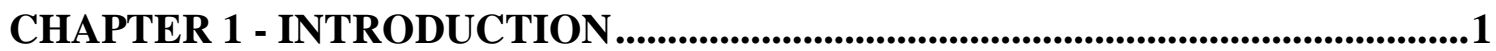

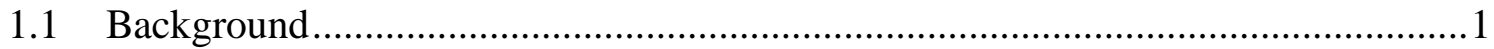

1.1.2 Visualization ..................................................................................

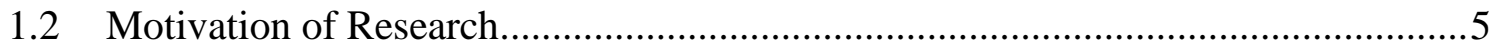

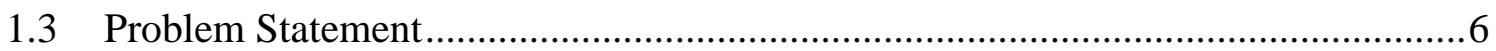

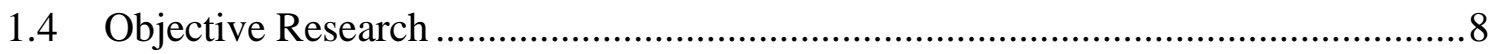

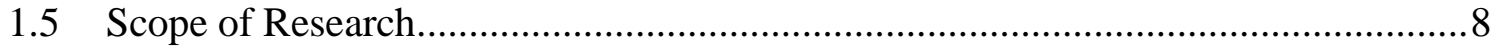

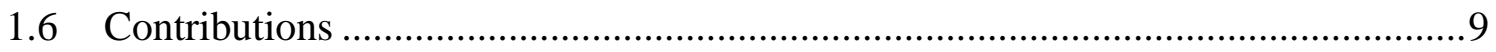

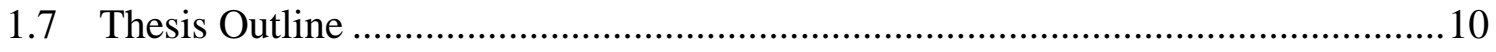

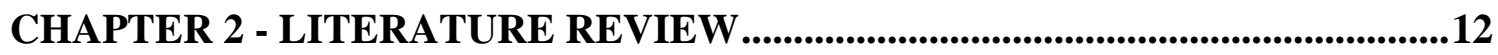

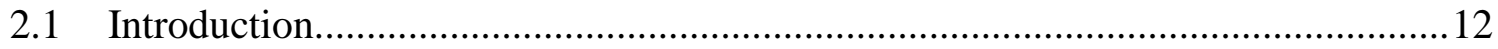

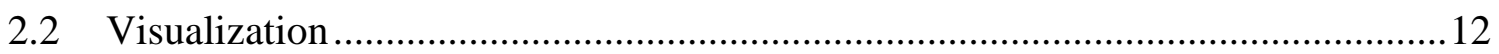




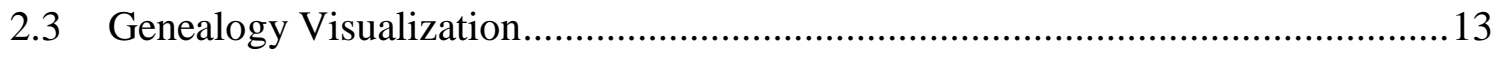

2.3.1 Treeplus ....................................................................................... 16

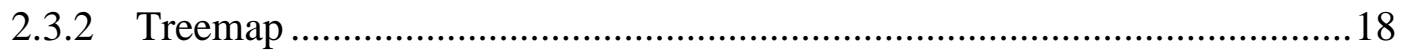

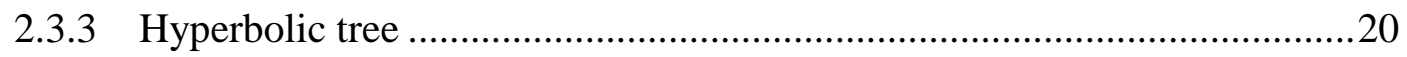

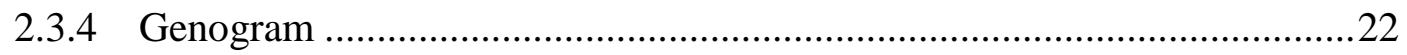

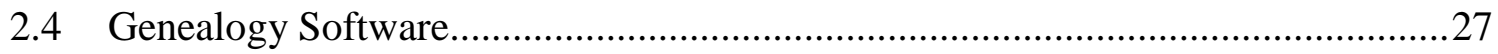

2.4.1 Family Tree Software ......................................................................2

2.4.2 Genogram Software ..........................................................................29

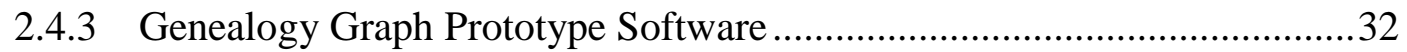

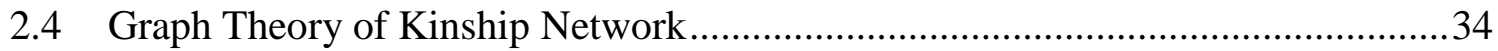

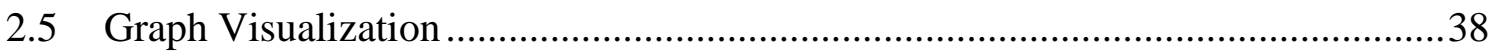

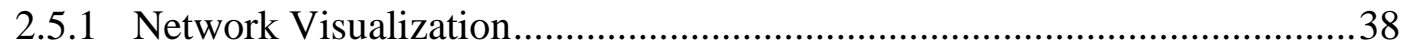

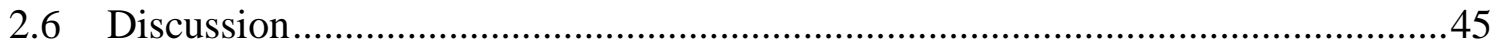

CHAPTER 3 - RESEARCH METHODOLOGY ................................................48

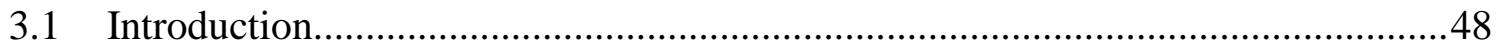

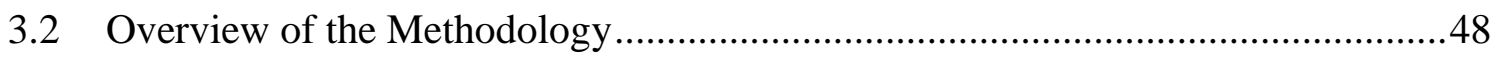

3.3 Designing the Framework and its Implementation .......................................50

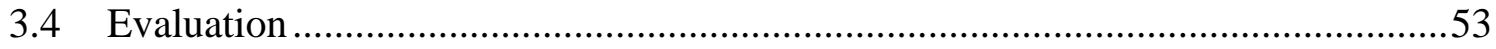




\section{CHAPTER 4 - DESIGNING THE FRAMEWORK AND ITS} IMPLEMENTATION .....................................................................56

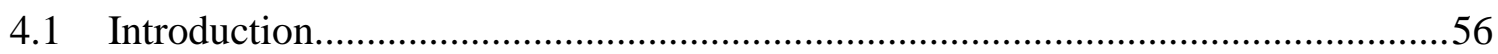

4.2 Designing the Proposed Framework ............................................................56

4.3 Designing the Visualization Approach .........................................................62

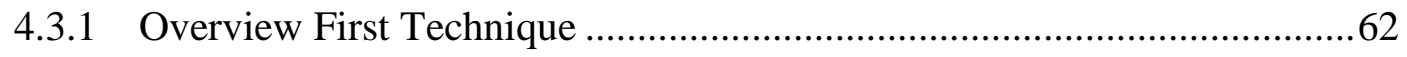

4.3.2 Zooming and Filtering Technique ....................................................66

4.3.3 Detail-on-Demand Technique .......................................................68

4.4 Calculating Risk Score using Analysis Method ..........................................69

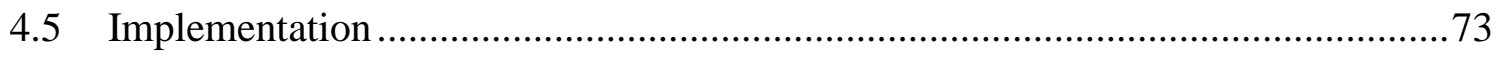

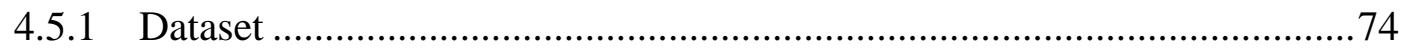

4.5.2 Implementation of "Overview first" Technique.......................................77

4.5.2(a) Layout algorithm, Size and Colour of Node and Label ...............78

4.5.3 Implementation of "Zooming and filtering” Technique.........................81

4.5.4 Implementing Detail-on-demand ................................................. 90

4.5.5 Implementation of Risk Score Calculation.......................................93

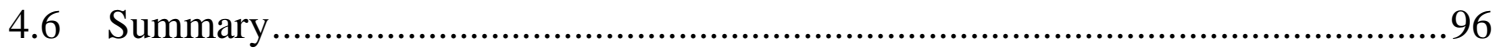




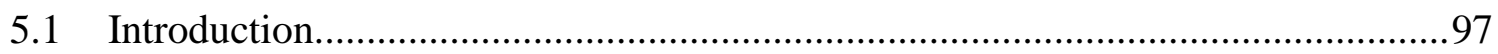

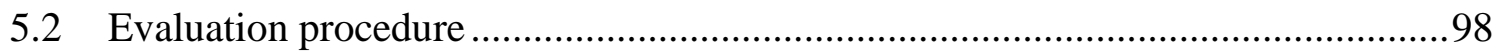

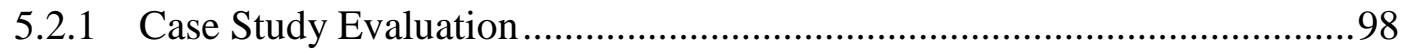

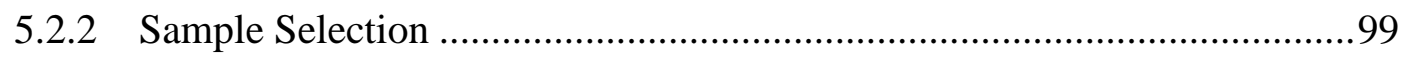

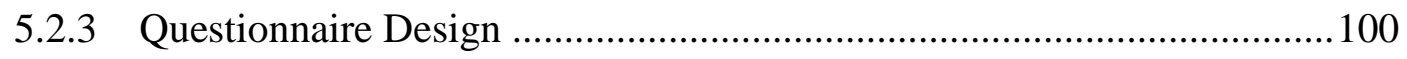

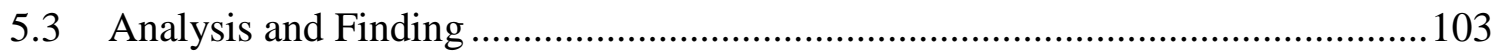

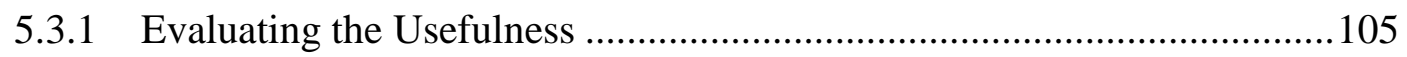

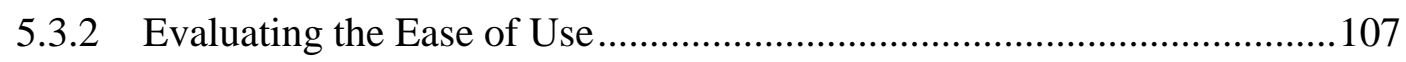

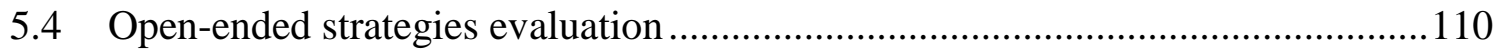

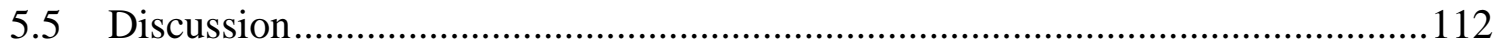

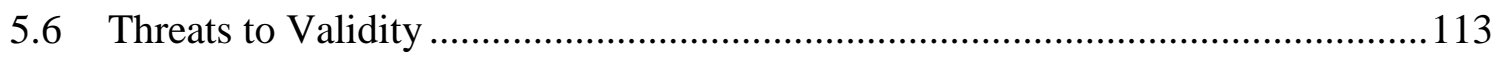

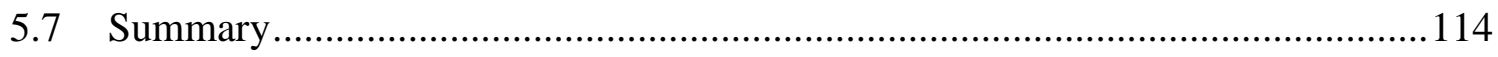

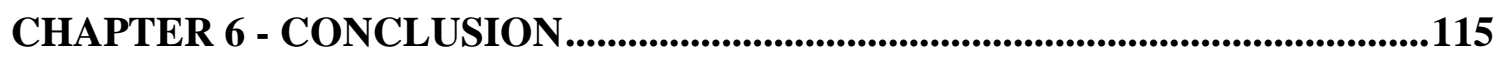

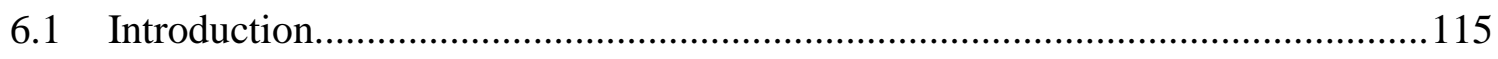

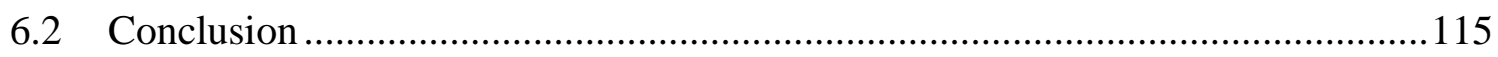

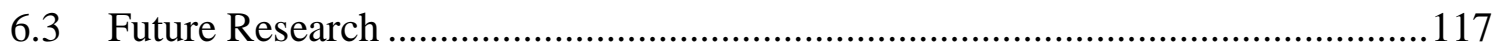

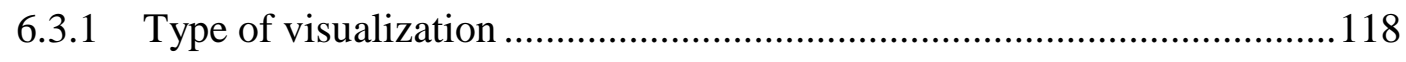

6.3.2 Automatic Risk Score Prediction ..................................................... 118 
REFERENCES .......................................................................................................................110

APPENDICES

LIST OF PUBLICATIONS 


\section{LIST OF TABLES}

Page

Table 5.1 Scale items of the usefulness and the ease of use concept

104

Table 5.2 Summary of the comments for the open-ended questions

111

viii 


\section{LIST OF FIGURES}

Page

Figure 1.1 Standard symbols for genograms

Figure $1.2 \quad$ Step by step visualization criteria

Figure 2.1 Common family tree layout

$\begin{array}{lll}\text { Figure 2.2 } & \text { Pedigree chart } & 14\end{array}$

$\begin{array}{lll}\text { Figure 2.3 Ancestry chart } & 15\end{array}$

$\begin{array}{lll}\text { Figure 2.4 Example of treeplus } & 17\end{array}$

$\begin{array}{lll}\text { Figure 2.5 } & \text { Example of treemap } & 19\end{array}$

$\begin{array}{lll}\text { Fiqure 2.6 } & \text { (a) Classical tree layout (b) Treemap layout } & 20\end{array}$

$\begin{array}{lll}\text { Fiqure 2.7 Example of hyperbolictree } & 21\end{array}$

$\begin{array}{lll}\text { Figure 2.8 } & \text { BRCA1 pedigree } & 24\end{array}$

Figure 2.9 Example of medical genogram 26

$\begin{array}{lll}\text { Figure 2.10 PAF companion } & 28\end{array}$

$\begin{array}{lll}\text { Figure 2.11 Myheritage } & 29\end{array}$

$\begin{array}{lll}\text { Figure 2.12 Genogram } & 30\end{array}$

Figure 2.13 Advannce Edraw 31

Figure 2.14 Dual tree genealogy visualization 33

$\begin{array}{lll}\text { Figure 2.15 Ore-graph } & 35\end{array}$

$\begin{array}{lll}\text { Figure 2.16 P-graph } & 36\end{array}$

$\begin{array}{lll}\text { Figure 2.17 } & \text { Bipartite p-graph }\end{array}$

Figure 2.18 Approaches to deal with large networks 40

Figure 2.19 Visualizing flow through a network 41 
Figure 2.20 SocialAction's technique on a subgraph from the global terrorism network

Figure 2.21 SocialAction's technique on a subgraph from the global terrorism network

Figure $3.1 \quad$ Research methodology

$\begin{array}{lll}\text { Figure 4.1 Proposed framework design } & 57\end{array}$

Figure 4.2 Diagram of causes of diabetes, hypertension and heart 59 disease

Figure 4.3 Standard gender symbols

$\begin{array}{lll}\text { Figure 4.4 } & \text { Family relationships key } & 60\end{array}$

$\begin{array}{lll}\text { Figure 4.5 } & \text { Medical genogram symbols (both gender) }\end{array}$

$\begin{array}{lll}\text { Figure 4.6 } & \text { Example of medical genogram }\end{array}$

Figure 4.7 Example of node-link diagram (disease and relationship) 64

Figure 4.8 Example of node-link diagram filtered using disease link 67 type

Figure 4.9 Ordered list for comparing ranking

Figure 4.10 Network visualization of eigenvector centrality measure $\quad 72$

$\begin{array}{lll}\text { Figure 4.11 Gephi architecture } & 73\end{array}$

$\begin{array}{lll}\text { Figure 4.12 Gephi overview } & 74\end{array}$

$\begin{array}{lll}\text { Figure 4.13 } & 75\end{array}$

Figure 4.14 Data imported into gephi data table 76

Figure 4.15 Assigning node with suitable data type (a) Node table (b) 77 Edge table

$\begin{array}{lll}\text { Figure 4.16 Ahmad multi-mode social graph } & 78\end{array}$

$\begin{array}{lll}\text { Figure 4.17 Node-link diagram overview } & 79\end{array}$ 
$\begin{array}{llr}\text { Figure 4.19 Data label visualization } & 80\end{array}$

$\begin{array}{llr}\text { Figure 4.20 } & \text { Filter library } & 82\end{array}$

$\begin{array}{lll}\text { Figure 4.21 Filtering on gender using the attribute equal filter window } & 83\end{array}$

Figure 4.22 Ahmad's network visualization filtered on male gender $\quad 84$

Figure 4.23 Filtering on type using the attribute partition filter window $\quad 85$

Figure 4.24(a) Ahmad's network visualization filtered on type of edges 86 (kind) which value is equal to "Hypertension"

Figure 4.24(b) Ahmad's network visualization filtered on type of edges 87 (kind) which value is equal to "Heart Disease"

Figure 4.24(c) Ahmad's network visualization filtered on type of edges 88 (kind) which value is equal to "Diabetes"

Figure 4.25 Filtering on age using the attribute range filter

Figure 4.26 Ahmad's network visualization filtered on age which value of age in a range of 10 to 69 years old

Figure 4.27 Ordered list of network segmentation of node and edge attribute

$\begin{array}{lll}\text { Figure 4.28 } & \text { Ordered list for degree ranking }\end{array}$

Figure 4.29 Network visualization of node coloured due to the result of 93 degree ranking in ordered list

Figure 4.30 Network visualization using eigenvector centrality measure

Figure 5.1 Model of usefulness, ease of use, and self-predicted future

101 usage

Figure 5.2 Score mean of usefulness

Figure 5.3 Comparison between the score mean for usefulness metric 106

Figure 5.4 Score mean of ease of use 
Figure 5.5 Comparison between the score mean for ease of use metric 


\title{
VISUALISASI GENOGRAM MENGUNAKAN PENDEKATAN RANGKAIAN SOSIAL BAGI PEPOHON SALASILAH KELUARGA
}

\begin{abstract}
ABSTRAK
Genogram adalah perwakilan grafik pepohon keluarga yang digunakan untuk menjejaki sejarah dan hubungan keluarga. Perwakilan ini memberikan gambaran keseluruhan tentang sejarah keluarga dan data genealogi yang membolehkan pengguna memahami dengan jelas maklumat umum dan kompleks keluarga mereka selama beberapa generasi. Namun, terdapat beberapa batasan semasa menggunakan genogram, iaitu masalah kebolehskalaan ketika memvisualisasikan kekayaan dan maklumat yang kompleks apabila pepohon keluarga semakin besar. Oleh itu, satu kerangka untuk meneroka data keluarga (genogram) menggunakan pendekatan rangkaian sosial dan kaedah analisis sebagai suatu peningkatan dicadangkan. Kerangka ini mengikuti reka bentuk panduan antara muka pengguna grafik canggih yang merupakan Mantra Maklumat Visual-Pencarian iaitu "Tijauan Keseluruhan Dahulu, Zum dan Tapis, kemudian Perincian-Mengikut Kehendak", yang dicadangkan oleh Shneiderman pada tahun 1996. Kajian ini memberi tumpuan kepada peningkatan interaksi dan pemahaman pengguna kepada data pepohon keluarga perubatan. Satu kajian kes telah dijalankan untuk menilai kegunaan dan kemudahan penggunaan alat prototaip ini. Telah ditemui bahawa alat prototaip yang menggunakan pendekatan rangkaian sosial meningkatkan pemahaman pengguna terhadap keluarga pepohon perubatan dari segi kegunaan dan kemudahan penggunaan. Menurut penilaian kerangka yang dicadangkan, alat ini boleh digunakan untuk kegunaan peribadi atau oleh profesional penjagaan kesihatan dan seterusnya membantu mereka memahami pepohon keluarga mereka dengan lebih baik.
\end{abstract}




\title{
GENOGRAM VISUALIZATION USING SOCIAL NETWORK APPROACH FOR MEDICAL FAMILY TREE
}

\begin{abstract}
Genogram is a graphical representation of a family tree that is used for tracking family history and relationships. It provides an overview of the family history and genealogy data which allow user to clearly understand the general and complex information of their family for several generations. But, some limitations exist while using genogram, namely scalability problems while visualizing the wealth and complex information once the family tree gets bigger. Hence, a framework for exploring medical family tree data (genogram) using social network approach and analysis method as an enhancement is proposed. This framework follows the design of advanced graphical user interface guide which is the Visual Information-Seeking Mantra that is "Overview First, Zoom and Filter, then Details-on Demand", proposed by Shneiderman in 1996. This research focuses on improving user interaction and understanding of medical family tree data. A case study has been conducted to evaluate the usefulness and ease of use of the prototype tool. It was discovered that the prototype tool which employ the social network approach improve user understanding of medical family tree in terms of usefulness and on ease of use. According to the evaluation of the proposed framework, the tool can be utilized for personal use or by healthcare professionals and furthermore it helps them to understand their medical family tree better.
\end{abstract}




\section{CHAPTER 1}

\section{INTRODUCTION}

\subsection{Background}

Genogram is one of the visual representations of genealogy which is similar to that of a family tree. Much like a family tree, the genogram graphically presents demographics with various shaped symbols and colour-coded lines. Genograms can depict a variety of information such as gender, age, ethnic origin, health status, education achievements, as well as different types of relationship such as family, social and emotional relationships. Important dates and any chosen characteristic such as personality, health and vocation of individual family members can also be input in a genogram (McGoldrick et al., 2008; Pendagast and Sherman, 1976).

Currently genograms are used by various groups of people in a variety of fields such as medicine, psychiatry, psychology, social work, genetic research, education and many more. Healthcare professionals have been using genogram as a tool to record important information about their patients and their family histories. The drawing of genogram has to conform to a set of rules in order for users to have the same understanding and obtain a similar interpretation of the genogram. Figure 1.1 shows some basic symbols for genogram. 

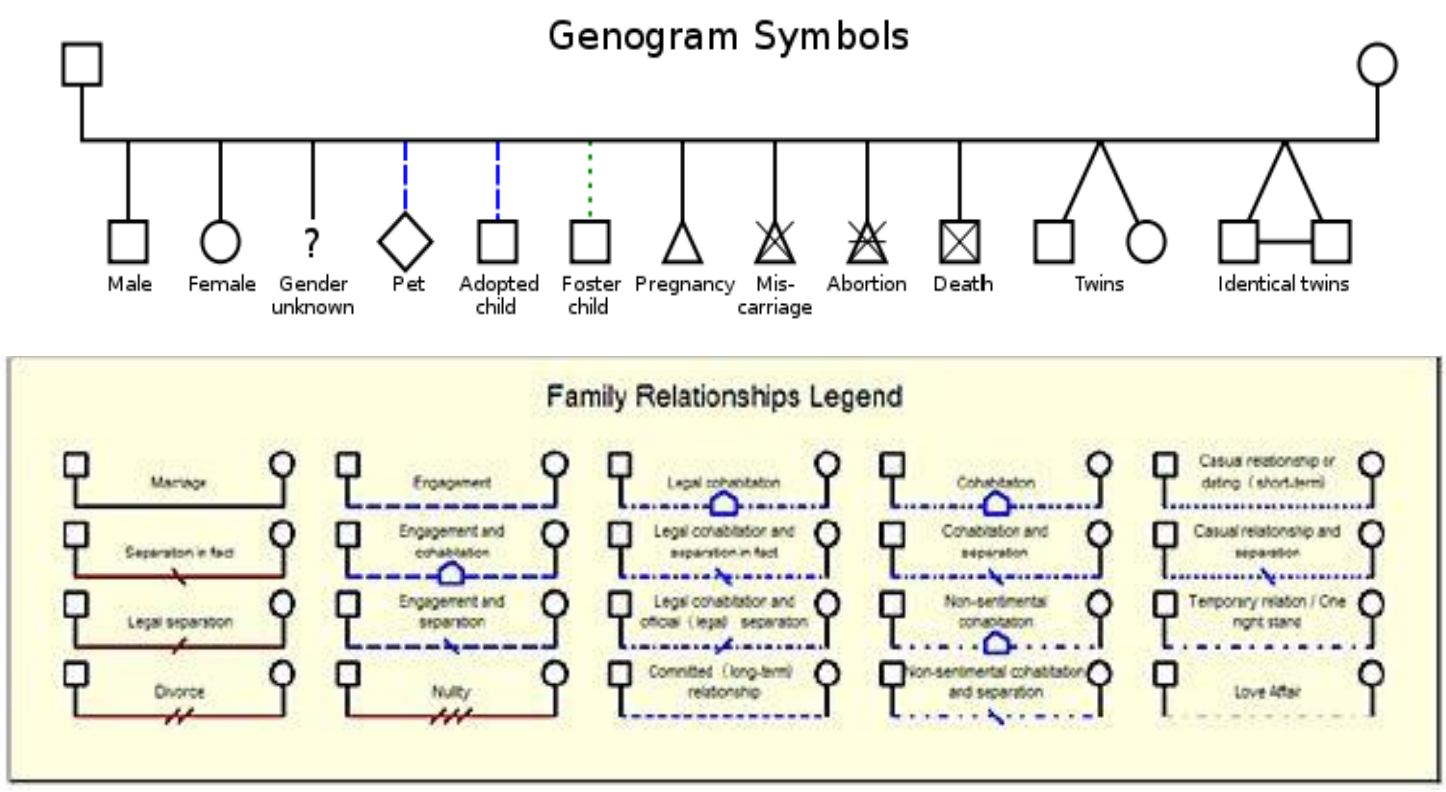

Figure 1.1 Standard symbols for genograms (McCormick et al.,1987)

The drawback of genogram is that it is highly dependent on the size and complexity of the relationships to be portrayed. There are existing software for generating family trees but problems exist due to non-interactive and scalability of trees which may affect the process to comprehend the genogram. This is because the nature of the genogram graphics could be complex and requires some advanced knowledge or detail explanations by those creating the symbol of genogram in order for others to understand the information displayed (Vivienne, 2010). 


\subsubsection{Visualization}

Generally, visualization is the transformation of data and information into pictures. One definition of visualization is to form a mental vision, image or picture of (something not visible or present to sight or of an abstraction); to make visible to the mind or imagination (The Oxford English Dictionary, Third Edition, 2010). The visualization of the data allows the user to gain insight into the data and come up with new hypotheses.

Nowadays the amount of data stored on electronic media is growing exponentially fast. Today's data warehouses dwarf the biggest databases built a decade ago (Kimball and Mer, 2000), and making sense of such data is becoming harder and more challenging.

According to McCormick et al. (1987) visualization is a method of computing which transforms the symbolic into geometric to enable researchers to observe their simulations and computations. Meanwhile Gershon (1994) define that visualization is more than a method of computing, it is about the process of transforming information into a visual form, enabling users to observe the information. In their understanding, visualization technology is based on the integration of older technologies, including computer graphics, image processing, computer vision, computer-aided design, geometric modelling, approximation theory, perceptual psychology, and user interface studies. Figure 2.1 shows where visualization maps the computer representation into images or animation. 


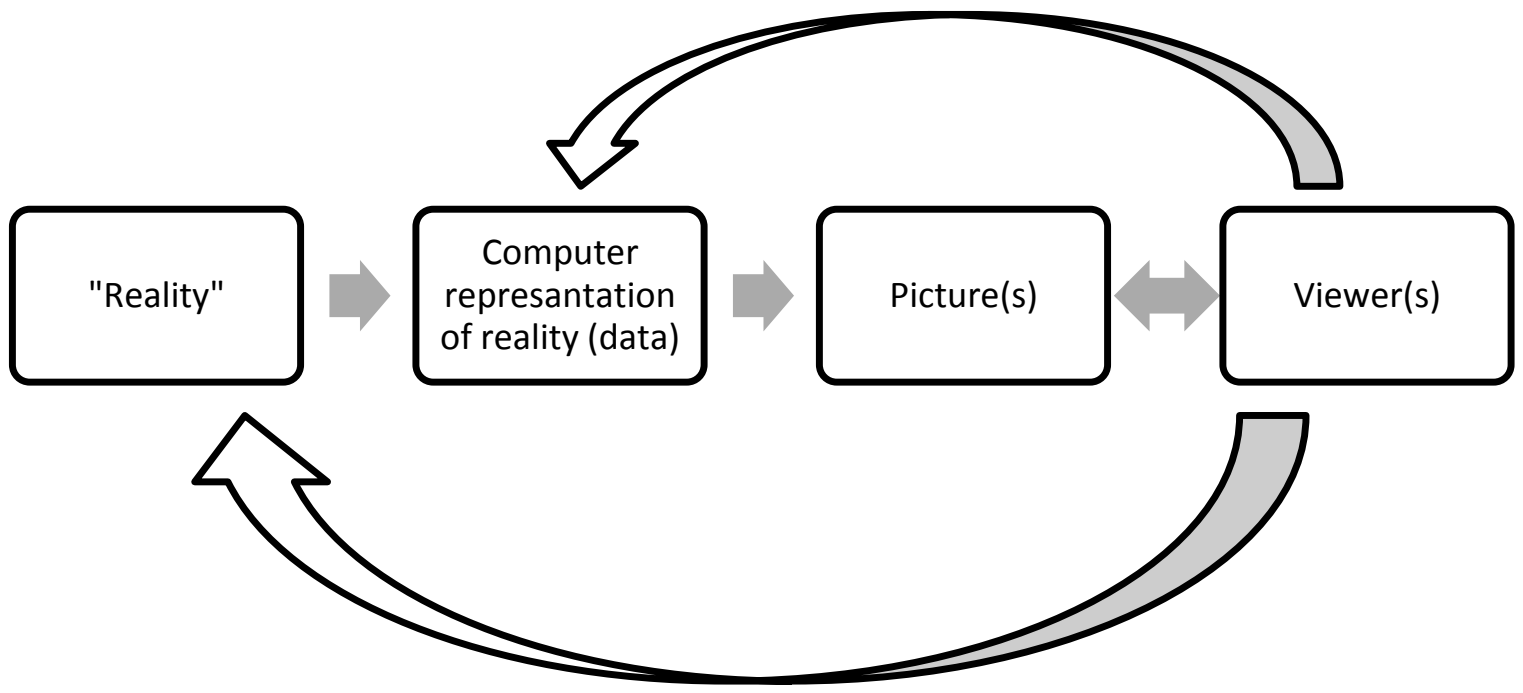

Figure 1.2 Visualization maps the computer representation of reality into perceptual (visual) representation (Domik and Gutkauf, 1994)

In the present day, visualization is used in many scientific areas. Each of these scientific areas has difference data types that need table visualization to be visualized. Keim (2002) has described six data types to be visualized: one-dimensional data (Spence and Apperley, 1982), two dimensional data (Laurini and Thompson, 1992; Egenhofer and Richards, 1993), multi-dimensional data (Inselberg, 1985; Williamson and Shneiderman, 1992;), text and hypertext, hierarchies and graph (Chimera and Shneiderman, 1993; Carriere and Kazman, 1995), algorithm and software. 
There are three criteria to be fulfilled in order to visualize data. Firstly, users need to recognize the data type and then try to find key issue for the specific data type. After that, apply a suitable visualization technique that will help to solve the key issue.

This research focuses on visualization interaction and understandability factors in medical family tree data. The object of interest for this research is medical genogram (medical family tree data). The main challenge of this research is how to visualize the medical genogram in order to increase user understanding, through improvement of interaction which leads to a better understanding of medical family tree data especially medical genogram. Hence this research attempts to address the scalability and clustering issue by proposing a visualization technique to improve user interaction and understandability of medical family tree.

\subsection{Motivation of Research}

Genogram constructs from various symbols and colour-coded lines that represent demographics information, health problem and addiction in individuals and among family members. Thus genogram have a lot of potential to be explored. As someone who is health conscious the researcher believes that medical genogram is very beneficial to be understood because apart from what people know from their family's tree and history, they can also find out about hereditary diseases that could be passed on from their parents to their offspring or descendants. Through this information, people will be more careful and take precautions towards the health problem. The use of different symbols in genogram will confuse the first time users. Furthermore excessive use of colour also contributes to the cluttered look when the family tree gets bigger. According 
to Ellis and Dix (2005), "too much data on too small an area of the display will result in visual clutter, which in turn diminishes the potential usefulness of the visualization, especially when the user is exploring the data".

The leading benefit of data visualization is that it does not only provide graphical representation of data but also allows changing of form, omitting what is not required and browsing deeper to get further details. This is a great eye catcher and attracts user's attention better and provides better communication. Furthermore, it provides a great advantage over traditional methods. Data visualization gives opportunity to approach huge data and makes it easily comprehensible. Thus to gain the full benefit of genogram data, users require a visualization tool that can present the data in a fully interactive environment conducive to exploration and also allow users to view their own custom data.

\subsection{Problem Statement}

Genogram contains a wealth of information on the family's history; therefore as a family tree gets bigger, visualizing becomes a more difficult task. Currently medical genograms use symbols, shape and colour-coded lines to represent information such as gender, age, ethnic origin, health status, as well as different types of relationship such as family. GenoPro, Genoware and WinGeno software package uses the symbols shown in Figure 1.1 to encode family's information. However, when the node expands, the genogram will looks confusing and cluttered by the use of different symbols and excessive use of colours (Keller et al., 2011). 
Understanding of a medical genogram is helpful in determining patterns of disease or illness within a family. But, the image-map format which is very limited in its ability to support gestural interaction leads to information perception difficulties and the visualization loses its initial purpose to understand the genogram (McGuffin et al., 2005). So, using social network visualization method to visualize the medical genogram reduces the node cluttered (scalability) and supports gestural interaction by using selected visualization technique (McGuffin and Balakrishnan, 2006) which improves user interaction and furthermore increases user understanding of their medical family tree data.

Health problems that run in the family can increase chances of developing the problem. This is because families share their genetics, environment, and habits (Genetic Alliance, 2009). But by knowing only patterns of disease does not help them to know the probabilities of inheritance. Therefore, visualizing statistical results (analysis score) will help user to gain new insight on health problem that affects their family from medical family tree data. 


\section{$1.4 \quad$ Research Objectives}

The aim of this research is to proposed a better framework for visualising medical family tree data. In more detail, it seeks to fulfil the following research objectives:

1. To design a visualization approach that improves user interaction and understanding of medical family tree data especially genogram in real-time.

2. To apply analysis method which provides user with visualization of analysis score that can improve the tool usability.

\subsection{Scope of Research}

The scopes of the research are as follow:

(i) Medical Genogram: Medical genogram is used as a tool for mapping family patterns by recording health information (including illnesses and medical conditions) about the patients and their family members. The family health information from three generation of relatives is needed in this research as a complete family history to map pattern of disorder among relatives (Biad, 2015).

(ii) Visualization technique: Visualization techniques can be used to visualize the medical genogram. This research focuses mostly on the visualization techniques that can used to explore the genogram, reduce scalability problem and create interactive environment to user. This research utilizes social network action visualization which implement the design of advanced graphical user interface guide known as Visual Information-Seeking Mantra "Overview first, zoom and filter, then details-on demand" (Shneiderman, 
1996). So, three visualization techniques have been used in this prototype tool.

(iii) Novices: This research focuses on beginners and novices as the target users. Users are treated as beginners or novices. This is because, whether they may have some experience or knowledge in tree scturture or medical family tree, the enviroment and experience is different when using the visualization tool. Futhermore, any assitance or guideline provided by using the visualization tool are more meaningful to them.

\subsection{Contributions}

Generally this research leads to a better understanding of family tree data. This research is expected to makes several contributions to the fields of medical health, genealogy and social network. By using social network visualization method and applying visual seeking mantra, a framework would be established which can present the data in an interactive environment that can assist user in understanding their medical family tree data better.

The analysis method applied in this framework provides statistical analysis of data that gives the user the ability to see its data from a new angle. The approach of Exploratory Data Analysis (Tukey, 1977) emphasizes the importance of curiosity and serendipity (i.e. discoveries made while searching for something else) to data analysis. This method provides a range of metrics for calculating statistics that characterize the data and used statistical results in the visualization by making use of colours and sizes to 
create informative visuals and make them particularly suitable for the visual exploration of data.

\subsection{Thesis Outline}

This thesis has six chapters that are organized in a chronological order consisting of an introduction, literature review, research methodology, the visualization technique, evaluation, and discussion respectively. The organization of this thesis is as follow:

Chapter 1 introduces the overview of family tree and genogram, background of the problems in genogram software. Furthermore, this chapter also explains on the research objectives and problem statement of this research. This chapter also describes the importance of this research, followed by the scope of this research. The theoretical framework for this research is designed and this is followed by a list of research contributions.

Chapter 2 reviews the existing works and some literature survey that are related to this research. Systematic literature review on the aspect of improving interaction and understandability of medical family tree data are explained in detail.

Chapter 3 outlines the research methodology. It provides detail on the procedure taken from the beginning to the end of the conducted research. Research procedures conducted in this study are illustrated and followed by explanations in the chapter. 
Chapter 4 explains the proposed work of this research that is VisualizeGENO. This chapter covers a detailed explanation of the proposed work and the algorithm involved in each component in the technique. Explanations on the design of the tool that is applied to the technique are also discussed in this chapter.

Chapter 5 presents in detail the procedures taken to evaluate the proposed technique and discussion results from the evaluation that has been conducted. The evaluation procedures include explanations on the experiment conducted, the sample selection for the case study and the design of the questionnaires. This research adopts a case study to evaluate the usefulness and ease of use of VisualizeGENO. It includes the analysis and findings of the case study as the evaluation of the proposed technique.

Chapter 6 provides the conclusion for this research. The contribution of the study is determined based on the findings. It also provides suggestions for future research work at the end of the chapter 


\section{CHAPTER 2}

\section{LITERATURE REVIEW}

\subsection{Introduction}

Visualization is important and helpful to support the exploration of large data sets. This chapter reviews some of the previous research related to the work in this thesis. It focuses on existing algorithms, techniques and applications that are currently available to address genogram visualization issues. The chapter is divided into five main sections. As Section 2.2 discusses on visualization usability, Section 2.3 will focus on genealogy visualization, Section 2.4 explanation on graph theory of kinship network, meanwhile Section 2.5 explanation focus on graph visualization and last but not least Section 2.6 presents the discussion for this chapter.

\subsection{Visualization}

The goal of visualization research is to transform data into a perceptually efficient visual format. Richard Mayer's Multimedia Learning book (2009) shows that "people learn more deeply when ideas are expressed in words and pictures rather than in words alone.' Colin Ware's Information Visualization book (2005) had listed four reasons why people use visualizations:

1. Visual displays provide the highest bandwidth channel from computer to the human.

2. Visualization provides an ability to comprehend huge amounts data.

3. Visualization allows the perception of emergent properties and patterns that were not anticipated. 
4. Visualization often enables problems with the data itself to become immediately apparent.

So, the reason to visualize genealogy research is to look at the alternatives. For example, by listing names and dates in a longer row does not help people gain insight into their genealogies as quickly as visualizing it, genealogical visualizations help people receive and understand data faster than any other medium such as reading text, sound, or tactile input. The next section explains on genealogy visualization.

\subsection{Genealogy Visualization}

Genealogy also known as family history is the study of family trees which plays an important role in history (e.g. of royal families, and of human migration), genetics, evolutionary biology, and in some cases, religion. Over the years, handcrafted charts have been used to illustrate genealogical relationships of a few dozen individuals in books. So the most widely used method of visualizing family history is to visualize it in a form of a tree often called a family tree (Figure 2.1). Beside that family history also represented in several formats, for example as a pedigree chart (Figure 2.2) or ancestry chart (Figure 2.3). 


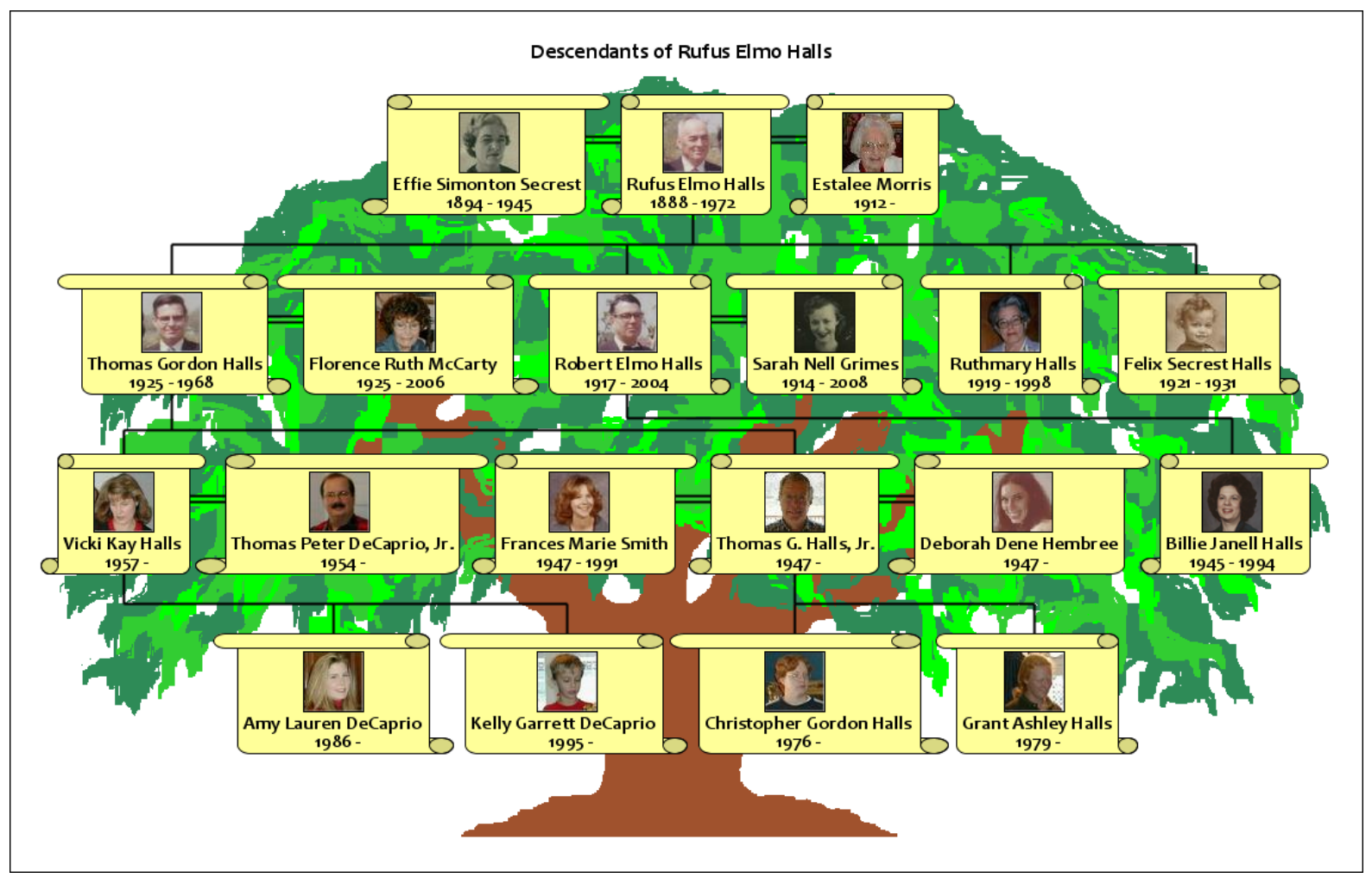

Figure 2.1 Common family tree layout taken from (cadapplet.com)

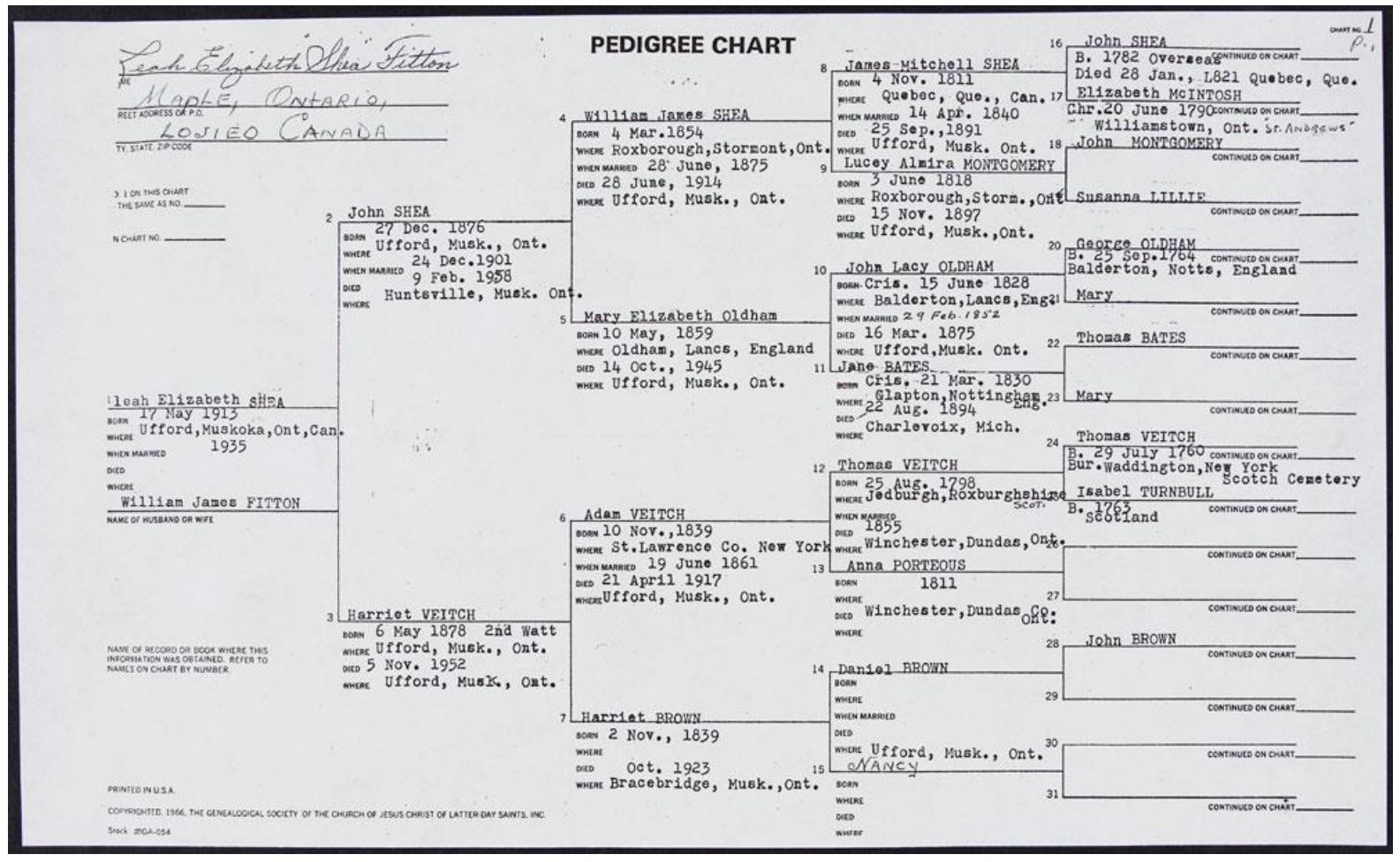

Figure 2.2 Pedigree chart taken from (Library and Archives Canada) 


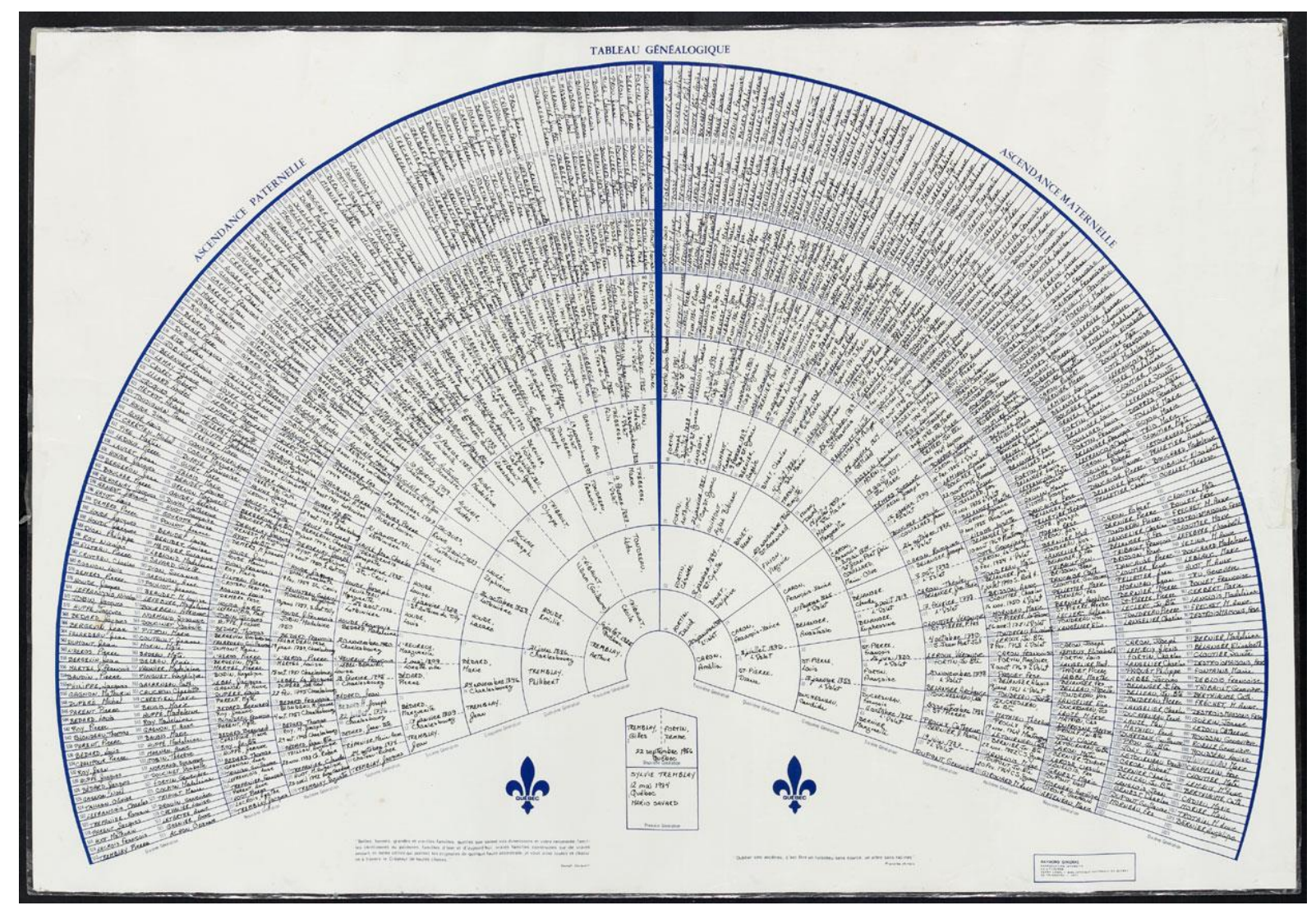

Figure 2.3: Ancestry chart taken from (Library and Archives Canada)

A family tree is a diagram representing family relationships which depicts a minimum of three generations in a conventional tree structure. There are two types of genealogical relations in every chart which is Parent-child relationships (consanguine relations) which define a hierarchy in genealogical data and Relationships through marriage (conjugal relations) are non-hierarchical and merge family trees (Nam Wook Kim et al., 2010). Together these form a network of relationships complex but simpler than a general graph. This is corresponding to constructing a tree of ancestors and a tree of descendants which this observation verifies why pedigree (Figure 2.8) and ancestry charts (Figure 2.10) are acknowledged charting methods for genealogical data. 
The main problem of tree layouts is on handling the size of the tree. Some layouts may effectively handle a tree with a few hundred of nodes but fail when it has a few thousand of nodes. A big number of nodes and edges lead to a high density of nodes, and it becomes impossible to interact with the tree and get any information from it. Thus careful analysis on layouts is needed to choose the suitable one which can solve a particular problem the best. It is beyond the scope of this paper to describe all the different types of layouts, however, this is the most common ones: Treeplus layout, Tree-map layout, hyperbolic tree. These layouts will be briefly discussed in the following sections, as well as some genealogy software packages.

\subsubsection{Treeplus}

Treeplus (Lee et al., 2006) involves converting graphs into trees and shows the missing graph structure with visualization and interaction techniques. TreePlus approach includes allowing preview of adjacent nodes, animating change of the tree structure, and giving visual hints about the graph structure. It allows users to begin with a specific node and incrementally explore the graph in detail and rapidly read labels to analyse the meaning of relationships. According to its author, TreePlus was inspired from the success of their earlier tools, SpaceTree and TaxonTree. Figure 2.4 shows example of TreePlus with the low density dataset used in the user study. 

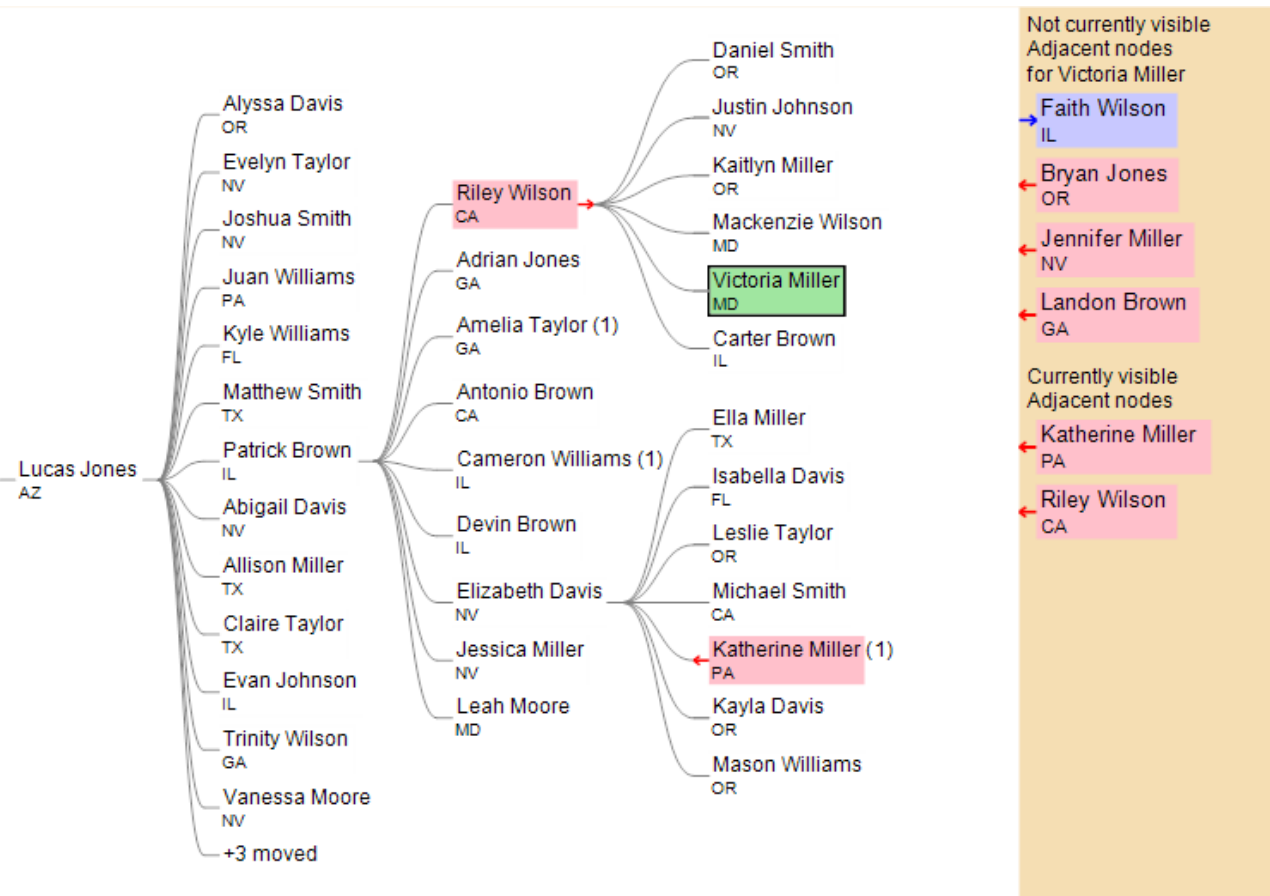

Figure 2.4 An example of TreePlus (Lee et al., 2006)

Treeplus applied pedigree chart layout. This layout shows that every node has its own line and therefore the number of lines needed to visualize the tree equals to the number of nodes in the tree. As the indentation can be visually perceived only a few lines at once, it becomes difficult to decide if the nodes are aligned or not in a large tree. For example it might happen that nodes that belong to the same level, e.g. sibling nodes, can be placed on lines that are far away from each other. Therefore it leads to usability issues when the layout is used to visualize large trees. 


\subsubsection{Treemap}

Treemap (Shneiderman, 1992) is a space-filling visualization method capable of representing large hierarchical collections of quantitative data. It is formed by using a rectangular display area and recursively subdividing it based on the tree structure, alternating between horizontal and vertical subdivision, and filling the terminal rectangular regions with a colour that can be used to represent different types of data. Treemap resulting from the idea to visualize files on a hard drive, have been used practically to a wide variety of domains ranging from financial analysis to sports reporting.

By using two-dimensional visualization technique for displaying the entire set of files, treemap will allow users to quickly recognise large files as candidates for deletion when the disk is full. Figure 2.5 shows example of a treemap. In this case, the amount of disk usage (indicated by the number beside each node) determines the size of the partition. The larger the disk usage, the greater the partition will be. Often, each partition is coloured based on file type. 


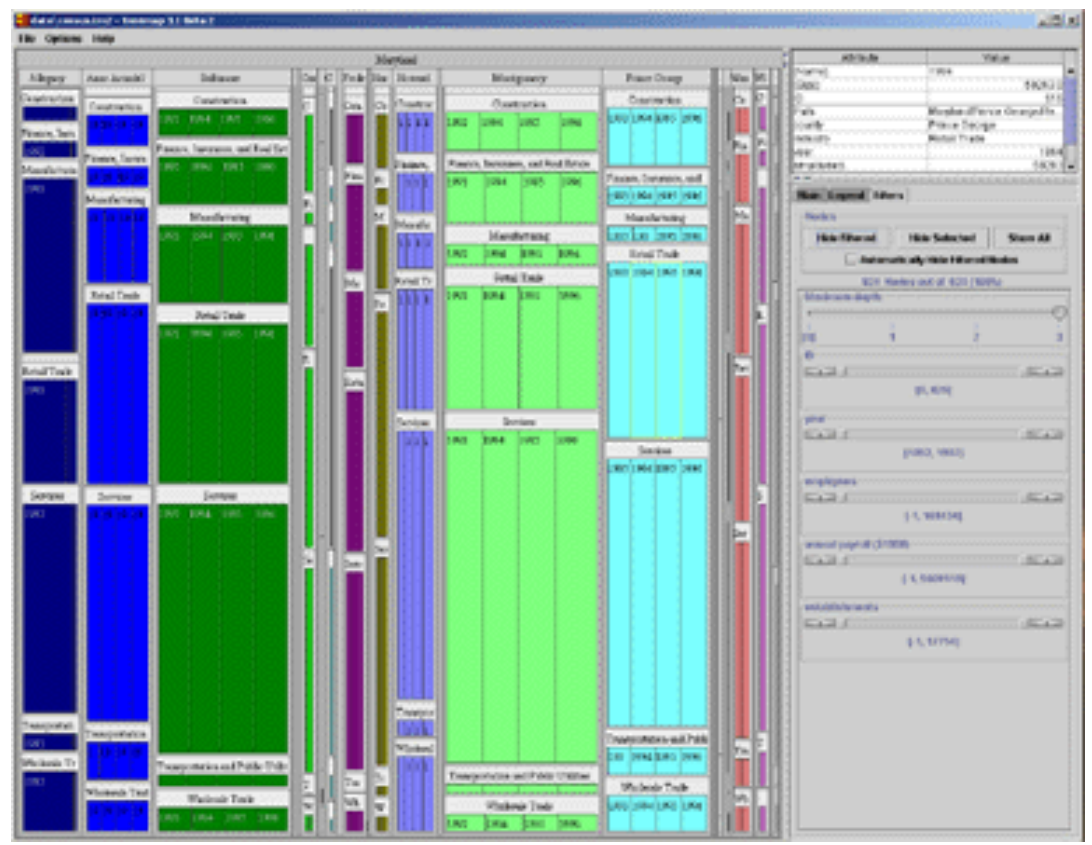

Figure 2.5 An example of treemap (Shneiderman, 2000)

According to Johnson and Shneiderman (1991), the following properties should hold:

1. If Node 1 is an ancestor of Node 2, then the bounding box of Node 1 completely encloses, or is equal to, the bounding box of Node 2 .

2. The bounding boxes of two nodes intersect if one node is an ancestor of the other. $\bullet$ Nodes occupy a display area strictly proportional to their weight.

3. The weight of a node is greater than or equal to the sum of the weights of its children.

Figure 2.6 show an example on how classical tree layout being visualize into tree map layout. The weight of each node is the size of the file or folder represented by that node. Figure 2.6, is a classical tree layout representing the file system structure. Every node in that tree has a label and a weight that is the size of that file or folder. The Treemap layout shown in Figure 2.6, b visualizes the same data. The figure clearly shows 
only the content of the leaf nodes, and it is difficult to extract the content from all the other internal nodes.
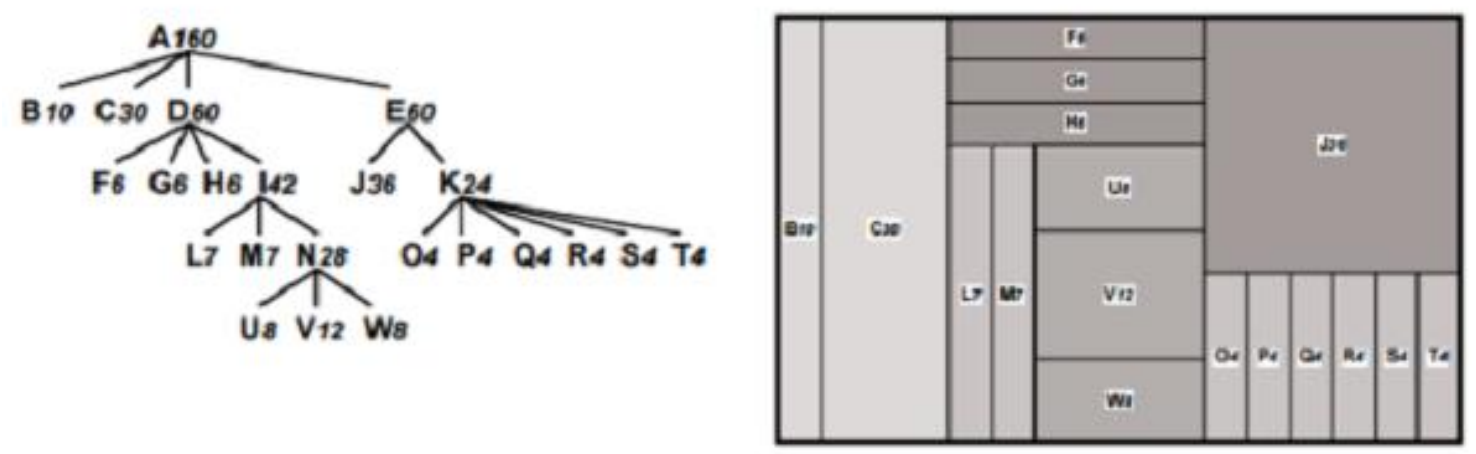

Figure 2.6 (a) Classical tree layout

(b) Tree-map layout, on the same hierarchical data

Information on how to apply the Tree-map layout to genealogy data rarely found. It is most likely because of the mentioned above limitation. Other reason might be in case of genealogy data, ways to assign weights to the nodes of the tree that determine the sizes of the rectangle it not very clear.

\subsubsection{Hyperbolic tree}

Hyperbolic Tree (Lamping and Rao, 1995), also called hypertree, employs hyperbolic space in which radial view laid out in it. This view is then mapped to an Euclidean plane so that an arbitrarily large tree fits within an oval-shaped area on the screen (see Figure 2.7). Hypertree using focus+context (fisheye) technique also known as hyperbolic browser, is used for visualizing and manipulating large hierarchies. The root is placed in the centre, and its children are fanned outward. Any part of the tree can be moved to the centre with a simple mouse-click or mouse-drag. 


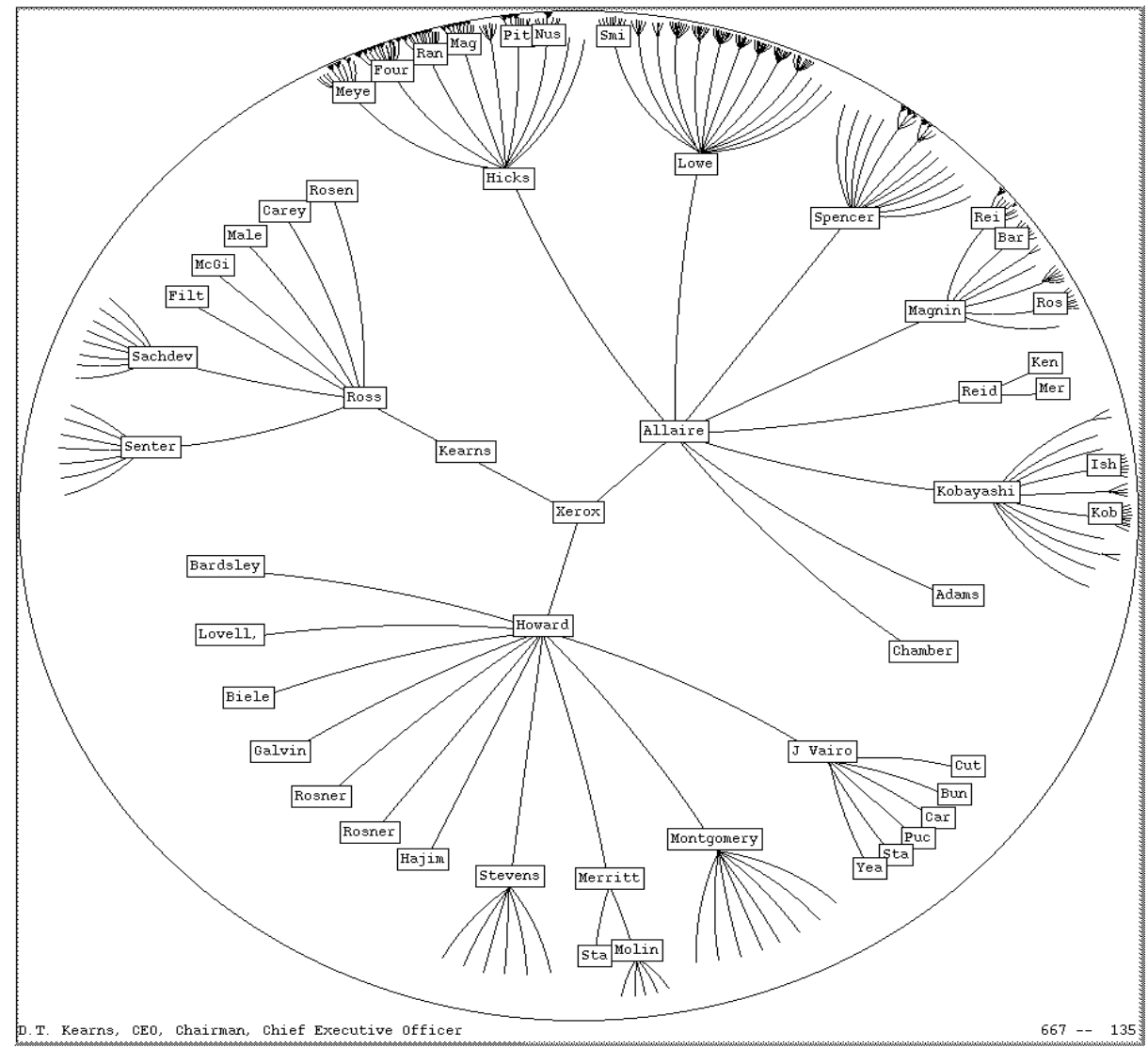

Figure 2.7 An example of hyperbolic tree (Lamping and Rao, 1995)

A hyperbolic tree follows the same basic principles as a common tree, with a link between a parent and a child. Users can easily grasp the hierarchical structure. However, since nodes are spread out evenly, users may find it hard in telling exactly how balanced or unbalanced a tree is. 


\subsubsection{Genogram}

Genogram is another visualization of genealogical data that is widely used in the medical field. A genogram is a graphic representation of a family tree that is used for tracking family history and relationships. It provides a detailed pictorial display of a family or groups that goes beyond a family tree in such a way that it contains information about genealogy and different types of relationship (Gill, 2003). It was first developed and popularized in clinical settings by a family therapist Monica McGoldrick and Randy Gerson by publishing their first book in 1985 (Kimball \& Mer, 2000). It resembles a family tree but is more sophisticated in its ability to provide particular kinds of information.

Genograms have been used for the last four decades as a tool for mapping family patterns and the psychological factors that interrupt relationships. They allow a practitioner to identify and understand repetitive patterns of behavior and to recognize hereditary tendencies; hence genograms are popular with healthcare professionals in areas such as social work, psychology, psychiatry, genealogy, genetic research, education and many more fields.

Other information that may be contained in a genogram depend on what people want to know; for example, if the purpose of a genogram is to map the medical history of a family, the genogram might include information such as hereditary patterns, genetics and psychological patterns. Clinical uses of genograms include gaining insight into clients' psyche (Friedman et al., 2009); as a data gathering device on individuals 
and families (Berthol et al., 2008). The development of various types of genogram such as cultural, socio-economic, ethical and career or work genograms is further evidence of the development and broader use of the tool over time (Fayyad et al., 1996).

\subsection{4(a) Medical Genogram}

Medical genogram is a genogram that has been used for medical purposes such as the family and biopsychosocial context of the patient's health and wellness issues (Blossom, 1992; Harbin, 1980; McGuinness, Noonan \& Dyer, 2005; Shellenberger \& Dwell, 1988; Zamudio and Hill, 2004). This genogram would include information family member relationship and also temporal information, such as the dates of birth, death, marriage and divorce, and also the occurrences of cancer. It could easily be elaborated upon to show what kind of work the individual family members were involved in or pertinent habits, such as smoking and drinking. When pertinent details are included, the genogram can help in clarifying and provide some understanding of how cancer has impacted this particular family. Health care providers use this genogram as a tool to record important information about a patient's in order to track family history and to look for recurring patterns of illness and behaviour (Shellenberger et al., 2007)

Medical genogram can be used to show the incidence of risk factors within a family. From the family history, risk factors can be extracted e.g. the number of first and second degree relatives with colorectal cancer, number of first and second degree relatives with stomach cancer. The person's age at which the relevant cancer developed is also very important and this also can be extracted (Gill, 2003). Figure 2.8, shows some of the classic features of a medical genogram with a deleterious breast and ovarian 
cancer syndromes 1 (BRCA1) mutation across three generations, including affected family members with breast cancer or ovarian cancer and a young age at onset.

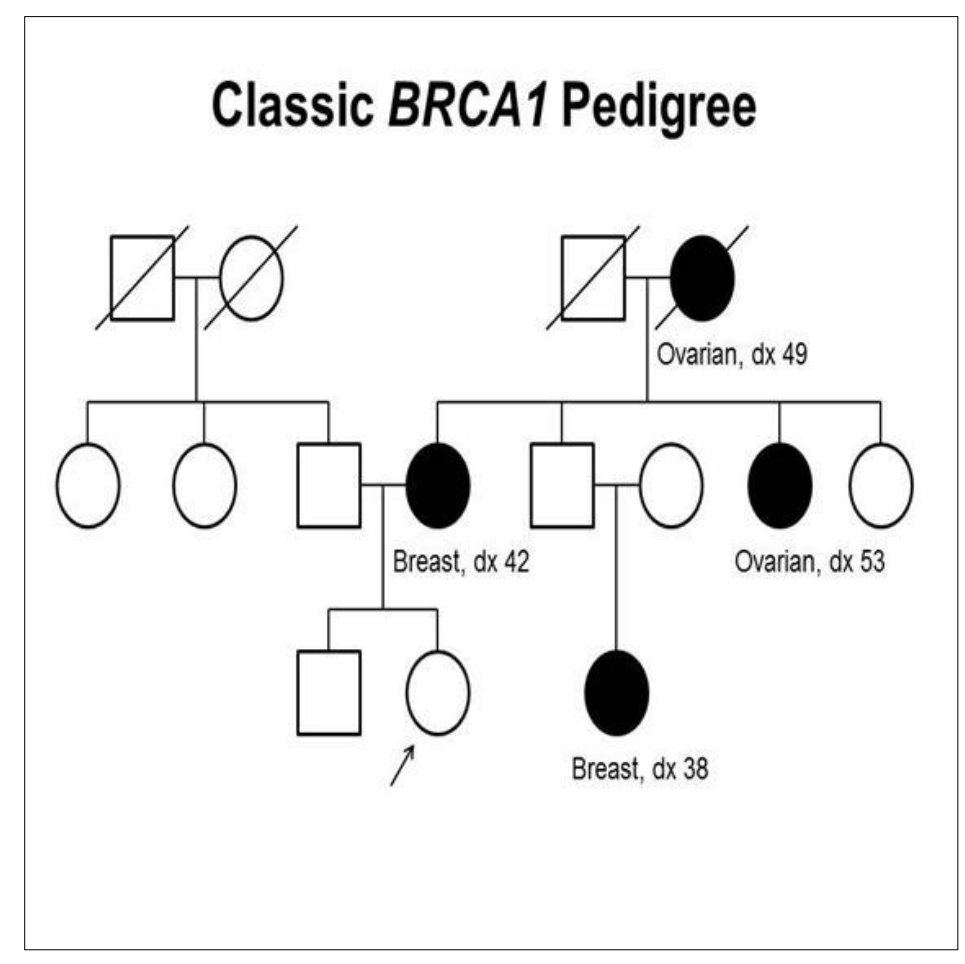

Figure 2.8: BRCA1 pedigree (National Cancer Institute, 2013)

Medical genogram is a very useful tool used to record health information of the patient and families. It does not only show the relationships among members of the patient's family, but it also includes relevant health information for each person (temporal information). This is because families have many factors in common, including their genes, environment and lifestyle. Together, these factors can give clues to medical conditions that may run in a family (Biad, 2015). By noticing patterns of disorders among relatives, healthcare professionals can determine whether an individual, other family members or future generations may be at an increased risk of developing a particular condition. For example, people with a higher-than-usual chance of having common disorders, such as heart disease, high blood pressure, stroke, certain cancers, 
and diabetes (Genetic, 2018). These complex disorders are influenced by a combination of genetic factors, environmental conditions and lifestyle choices (Hernandez \& Blazer, 2006). So it will help the patient and other family member to notices a pattern of disease in their family.

To visually encode disease information various shaped, colored symbols and lines are used. The use of genograms is growing, and the genograms and the symbols are expanded and modified. Different software packages use their own conventions on how to visually encode information with different symbols and colors. Moreover, some of those software packages allow users to add custom symbols or change existing ones to reflect the current needs. Even though it adds flexibility to the tools, it is at the same time a drawback as there is no consistency in the visualization between different software packages. That requires training when changing from one tool to another. Moreover, it can lead to inaccurate or incorrect analysis results. Figure 2.9, shows an example of medical genogram created for three generation using GenoPro software. 